Zbigniew Gruszka

Łódź

\title{
Udział Józefa Grycza w pracach nad „Przeglądem Bibliotecznym” w latach 1927-1939
}

„Przegląd Biblioteczny” jest najstarszym naukowym czasopismem bibliotekarskim, ukazującym się nieprzerwanie (z wyjątkiem okresu II wojny światowej) od 1927 roku. Prekursorem pisma był periodyk o takim samym tytule, wydawany w latach 1908-1911 w Bibliotece m. st. Warszawy.

„Przegląd” od ponad 80 lat służy rozwojowi naukowemu bibliotekarzy i bibliologów, a ustalony w roku powstania charakter pisma pozostał niemal niezmieniony. Pismo poświęcono publikowaniu artykułów dotyczących teorii i praktyce technik bibliotekarskich, historii i organizacji bibliotek (głównie naukowych). Od początku funkcjonowania periodyku jego łamy były otwarte na sprawy zawodu bibliotekarza, prace księgoznawcze oraz dotyczące historii i filozofii książki. „Przegląd” obejmował nadto recenzje, przeglądy czasopism, kronikę wydarzeń oraz bibliografię prac bibliotekarskich, księgoznawczych, bibliograficznych i bibliofilskich. Taki układ treści czasopismo zachowało jeszcze po II wojnie światowej, do lat sześćdziesiątych XX wieku ${ }^{1}$.

O roli „Przeglądu” w rozwoju bibliotekoznawstwa i informacji naukowej świadczy fakt, iż był on „motorem” i głównym polem dyskusji nad książką i biblioteką. Od początku XX wieku, to jest od chwili, gdy redakcji „Przeglądu” podjął się Stefan Demby (1908), a następnie Stanisław Krzemiński (1909), osoby skupione wokół pisma poruszały zagadnienia produkcji i udostępniania książki, organizowania i prowadzenia bibliotek, instytucji kultury. Wśród postaci współtworzących czasopismo byli m.in. Karol Badecki, Ignacy Chrzanowski, wspomniany Stefan Demby, Samuel Dickstein, Stanisław Michalski, Władysław Mickiewicz, Stanisław Posner i inni.

${ }^{1}$ M. Banacka, B. Sosińska-Kalata, „Przeglad Biblioteczny” - rocznik 1927, Przegl. Bibliot., 75:2007, z. 4, s. 528 . 
W wyniku trudności finansowych warszawska inicjatywa wydawania „Przeglądu Bibliotecznego” została zawieszona w 1911 r., jednak myśl o potrzebie istnienia periodyku, który byłby płaszczyzną do prowadzenia naukowych dysput cyklicznie powracała w 1911, 1919 i 1921 roku. Przełomowym momentem okazał się II Zjazd Bibliofilów Polskich w Warszawie w 1926 roku, podczas którego przeważały zagadnienia organizacji stanu bibliotekarskiego (związane $\mathrm{z}$ tworzeniem i funkcjonowaniem bibliotek, czy określeniem wymagań zawodowych stawianych bibliotekarzom), plany opracowania przepisów katalogowania i inne. Płaszczyzną do dyskusji nad tą problematyką miało być czasopismo fachowe ${ }^{2}$. W Zjeździe, zdominowanym przez tematykę bibliotekarską ${ }^{3}$, wzięli udział m.in. Wacław Anczyc, Ludwik Bernacki, Stefan Demby (prezes komitetu organizacyjnego), Franciszek Biesiadecki, Rudolf Kotula, Edward Kuntze, Wacław Olszewicz, Zenon Przesmycki (Miriam). W ramach sekcji bibliotekoznawczej prowadzonej przez Kuntzego referat porównawczy na temat polskich przepisów katalogowania wygłosił Józef Grycz, którego efektem było skierowanie do Ministerstwa Wyznań Religijnych i Oświecenia Publicznego wniosku o rozpatrzenie istniejących instrukcji i opracowanie przepisów katalogowania obowiązujących wszystkie biblioteki w Polsce ${ }^{4}$.

Józef Grycz opublikował jeszcze dwie prace sprawozdawcze ze zjazdów. Pierwszą z nich jest sprawozdanie z I Zjazdu Bibliofilów Polskich w Krakowie w 1925 roku $^{5}$, drugą - praca poświęcona III Zjazdowi Bibliofilów Polskich we Lwowie w 1928 roku6 ${ }^{6}$. Ciekawe, iż pierwsze

2 I. Turowska-Bar, Edward Kuntze jako redaktor „Przegląu Bibliotecznego”, Przegl. Bibliot., 25:1967, z. 2, s. 110.

${ }^{3}$ W zamieszczonym w „Przewodniku Bibliograficznym” (1926, nr 11, s. 512) sprawozdaniu z II Zjazdu Bibliofilów J. Grycz pisał: „Trzeba było dopiero zjazdów bibliofilskich, aby stało się widocznem, jaka moc spraw zalega i jak wiele energii i ochoty do pracy czeka wyzwolenia wśród bibliotekarzy. Skorzystali oni z nadarzającej się sposobności: zmajoryzowali zjazd warszawski, przekształcając go niemal w zupełności na zjazd bibliotekarski”. Por. także Drugi Zjazd Bibliofilów Polskich w Warszawie, Lwów-Warszawa, 1927, s. 3.

${ }^{4}$ Tamże. Autorem sprawozdania z prac sekcji bibliotekarskiej był J. Grycz.

5 Pierwszy Zjazd Bibliofilów Polskich w Krakowie, 28-30 czerwca 1925: sprawozdanie, Kraków 1926.

${ }^{6}$ J. Grycz, Trzeci Zjazd Bibliofilów Polskich we Lwowie, Kraków 1929. Grycz w sprawie przepisów katalogowania w polskich bibliotekach wypowiedział się jeszcze w „Przeglądzie" w 1932 r., gdzie zamieszczony został jego referat z III Zjazdu Bibliotekarzy Polskich (Wilno, 26-28 VI 1932). Por. tenże, Na drodze do polskiej instrukcji alfabetycznego katalogowania (streszczenie referatu), Przegl. Bibliot., 6:1932, z. 3-4, s. 147-148. Pod krótkim tekstem A. Łysakowski dziękował Gryczowi za ,[...] dotychczasową pracę nad ogólno-polską instrukcją katalogowania alfabetycznego” i prosił o „doprowadzenie tej ważnej sprawy do końca”. Por. tamże, s. 148. 
publikacje wydał Grycz już w 1925 roku, w trzy lata po związaniu się z bibliotekarstwem; były to: $O$ polskie przepisy katalogowania, Przewodnik dla korzystajacych $z$ bibliotek oraz spis dziet pomocniczych oraz Katalog biblioteki podręcznej czytelni oraz biura katalogowego ${ }^{7}$.

Praca zawodowa podjęta w Bibliotece Jagiellońskiej w 1922 r. umiejscowiła Grycza w centrum aktywnej i nowatorskiej działalności bibliotekarskiej, której owocem było powołanie w Krakowie w 1927 roku centralnego organu naukowego bibliotekarstwa polskiego, „Przeglądu Bibliotecznego”. Józef Grycz, wraz z Aleksandrem Birkenmajerem, bibliotekarzem Biblioteki Jagiellońskiej, był współzałożycielem pisma i od początku brał udział w jego wydawaniu, a następnie w latach 1927-1928, był sekretarzem redakcji. Związane $\mathrm{z}$ tym zadania w całości pochłonęły go. W liście do Adama Łysakowskiego tak pisał o pracy sekretarza:

Nareszcie po długiej przerwie, spowodowanej wielkim nawałem zajęć w bibliotece [tj. w Bibliotece Jagiellońskiej - Z.G.], a zwłaszcza w »Przeglądzie [Bibliotecznym]«, odzywam się do Kochanego Pana Kolegi. [...] Nowy zeszyt »Przeglądu« będzie w tym tygodniu cały złożony, rozpocząłem już korekty i uzupełnienia. Pański artykuł będzie oczywiście umieszczony, proszę tylko o łaskawą wiadomość, czy i ile odbitek mamy zrobić, gdyż idzie to na koszt autora ${ }^{8}$.

W tym samym liście pytał Łysakowskiego, jak mu i jego współpracownikom podobał się zeszyt już wydany, prosił też o dezyderaty i spostrzeżenia, które udoskonaliłyby pismo ${ }^{9}$. Z korespondencji Grycza z Łysakowskim, opublikowanej przez Marię Dembowską, wyłania się obraz osoby skrupulatnej i pochłoniętej pracą. Grycz był odpowiedzialny za kontakty autorów z redakcją, sprawował pieczę nad tekami redakcyjnymi, realizował honoraria autorskie, odpowiadał za druk, korekty i terminowe ukazywanie się pisma. Zwłaszcza w pierwszych latach „Przeglądu” było to zadanie niezwykle trudne, pismo bowiem przez całe dwudziestolecie międzywojenne borykało się z kłopotami finansowymi. Poza tym, zachowując terminowość druku, trudno było utrzymać wysoki poziom

${ }^{7}$ Okoliczności powstania tych prac i reakcję środowiska bibliotekarskiego przedstawia szczegółowo: B. Horodyski, Józef Grycz, [w:] Z zagadnień teorii i praktyki bibliotekarskiej. Studia poświęcone pamięci Józefa Grycza, Wrocław 1961, s. 24-26.

8 J. Grycz do A. Łysakowskiego, Kraków 29 II 1928, [w:] Bibliotekarstwo polskie 1925-1951 w świetle korespondencji jego wspóttwórców, wyboru z listów Adama Lysakowskiego, Mariana Łodyńskiego, Józefa Grycza, Heleny Hleb-Koszańskiej dokonała, wstępami, przypisami i indeksem opatrzyła Maria Dembowska, Warszawa 1995 (dalej cyt. Bibliotekarstwo polskie...), s. 207.

${ }^{9}$ Tamże, s. 208. 
merytoryczny pisma, publikującego przede wszystkim artykuły o charakterze historycznym i prace księgoznawcze. Zagadnienia dotyczące technik i organizacji prac bibliotecznych zamieszczano w periodyku tylko wtedy, gdy były sprawdzone i wypróbowane. Redakcja odcinała się od zagadnień aktualnych, wymagających dyskusji, uważając, że „Przegląd” się do tego nie nadaje ${ }^{10}$.

W ciągu dwóch lat pracy na stanowisku sekretarza periodyku Grycz opublikował w na jego łamach szereg drobniejszych prac, które podpisywał inicjałami. W $1927 \mathrm{r}$. skupił się na sprawozdaniach zamieszczanych w dziale „Kronika”. Były to głównie bogate dane statystyczne z działalności Biblioteki Jagiellońskiej w latach $1918-1927^{11}$ oraz opis Centralnej Biblioteki Nauczycielskiej Okręgu Szkolnego Krakowskiego ${ }^{12}$. Figuruje też w „Kronice” kilka niepodpisanych prac, których autorem (bądź współautorem) mógł być Grycz ${ }^{13}$.

W drugim roczniku „Przeglądu” (1928 r.), mimo dokumentowanej pracy sekretarza redakcji, nie odnajdujemy publikacji autorskich Grycza w żadnym z numerów pisma. Pewne jest, że jeszcze 15 września 1928 roku trudził się nad wydaniem kolejnego zeszytu, o czym pisał do Łysakowskiego:

Za list mogę odwdzięczyć się tylko karteczką, gdyż po uszy siedzę w robocie, a i tak »Przegląd « się spóźni. [...] ciągle żyję w niepewności. Jakoś się ta ostateczna decyzja odwleka i nie wiem co jest tego powodem ${ }^{14}$.

Ostatnie słowa listu dotyczyły niepewności Grycza co do spodziewanego przeniesienia go do Biblioteki Kórnickiej. Decyzję o obsadzeniu na stanowisku kierownika tejże biblioteki Zarząd Fundacji Zakłady Kórnickie podjął ostatecznie 19 września 1928 r. Służbę biblioteczną w nowym miejscu pracy Grycz rozpoczął 1 października tegoż roku ${ }^{15}$, co spowodowało przenosiny do Wielkopolski i opuszczenie redakcji „Przeglądu".

10 J. Grycz, Pierwsze dziesięciolecie „Przegląu Bibliotecznego”, Przegl. Bibliot., 11:1937, z. 1, s. 2.

11 J. G[rycz], Biblioteka Jagiellońska w latach 1918-1927, Przegl. Bibliot., 1:1927, s. $143-148$.

12 J. G[rycz], Centralna Biblioteka Nauczycielska Okregu Szkolnego Krakowskiego, Przegl. Bibliot., 1:1927, s. 171-174.

${ }^{13}$ Są to m.in.: Biblioteka Muzeum X.X. Czartoryskich w Krakowie, s. 167-168; Centralny katalog czasopism zakładów Uniwersytetu Jagiellońskiego, s. 182-183; Rzut oka na rok 1927, s. 187-192; Wydawnictwa Wileńskiego Koła Zwiazku Bibliotekarzy Polskich, s. 192.

14 J. Grycz do A. Łysakowskiego, 15.9.1928, [w:] Bibliotekarstwo polskie..., s. 210.

${ }^{15}$ Bibliotekarstwo polskie..., s. 241, przyp. 14. 
Funkcje sekretarza redakcji pisma objął Władysław Pociecha. Grycz, dzięki uwolnieniu się od nawału pracy, rozpoczął publikowanie na łamach „Przeglądu” licznych artykułów. Już w rok po objęciu stanowiska dyrektora przedstawił w piśmie swoją wizję Biblioteki Kórnickiej, w której uwzględnił zarówno profil gromadzenia księgozbioru, jak i aspekty finansowe funkcjonowania placówki. Obok biblioteki zaplanowano Muzeum. Znajdująca się pod opieką fundacji instytucja miała podjąć się regularnej i utrzymanej na wysokim poziomie merytorycznym działalności wydawniczej ${ }^{16}$.

Wypowiedzi Grycza nie zabrakło w zeszycie specjalnym „Przeglądu”, poświęconym II Zjazdowi Bibliotekarzy Polskich w Poznaniu w 1929 roku. Udział w jego zorganizowaniu miała Biblioteka Kórnicka oraz Józef Grycz. Spotkanie nawiązywało do setnej rocznicy pierwszego wydawnictwa Biblioteki. W koreferacie nawiązującym do wystąpienia Adama Łysakowskiego na temat norm organizacyjnych w bibliotekarstwie, Grycz zgodził się i podtrzymał poglądy o konieczności ustalenia teoretycznych i praktycznych warunków normalizacji pracy bibliotek naukowych, a w szczególności uniwersyteckich. Grycz był przekonany o potrzebie usprawnienia pracy bibliotekarzy. Wprowadzenie standardów bibliotecznych uzasadniał różnymi okolicznościami powstania bibliotek naukowych w miastach II Rzeczpospolitej. Unifikacji wymagały przede wszystkim przepisy katalogowania, formy opracowania katalogów, ponadto planowano centralny katalog zbiorów, przemyślany dobór personelu, a także jednolitą politykę dotyczącą egzemplarza obowiązkowego. Normalizację widział jako proces długofalowy, uzależniony od możliwości finansowych instytucji i stopnia realizacji zapoczątkowanych prac ${ }^{17}$.

Uczestniczący w zjeździe bibliotekarze i bibliolodzy nie mieli zastrzeżeń do wystąpień Łysakowskiego i Grycza. Efektem obrad było wystosowanie pisma do Ministerstwa Wyznań Religijnych i Oświecenia Publicznego z prośbą o zwiększenie funduszy na funkcjonowanie bibliotek uniwersyteckich i o zwołanie zebrania dyrektorów placówek, na którym omówiono by zakupy publikacji zagranicznych ${ }^{18}$.

W 1930 r. Grycz podjął się realizacji ogłoszonych rok wcześniej tez odnośnie właściwego doboru personelu i opublikował pracę na temat

${ }^{16}$ J. Grycz, Polityka Biblioteki Kórnickiej. Rzut oka w przeszłość i przyszłość, Przegl. Bibliot., 3:1929, z. 2, s. 115-116.

17 J. Grycz, Normy organizacyjne bibliotek naukowych a w szczególności uniwersyteckich (koreferat), Przegl. Bibliot., 3:1929, z. 3-4, s. 307-308.

18 Tamże, s. 310. 
organizacji kursów bibliotekarskich. Nawiązując do poglądów Kuntzego, wyłuszczył w niej podstawy finansowe, merytoryczne i organizacyjne takich szkoleń, których głównym punktem miała być edukacja w zakresie tworzenia i opracowania katalogów bibliotecznych; kurs miał objąć bibliotekarstwo, księgoznawstwo, bibliografię, bibliotekoznawstwo i naukę o konstytucji.

Szczegółowy plan szkolenia świadczy o rozeznaniu Grycza w oczekiwaniach pracodawców wobec zatrudnionych w bibliotekach naukowych osób oraz o znajomości zagadnień, z którymi spotykali się pracownicy bibliotek. Swoją koncepcję pozostawił do przedyskutowania; przewidywał rozpoczęcie kursów jeszcze w 1930 roku ${ }^{19}$.

Gdy w tymże roku Jan Kossonoga wysunął propozycję przeniesienia redakcji „Przeglądu Bibliotecznego” do Warszawy, Józef Grycz miał już ugruntowaną pozycję w środowisku bibliotekarskim. Jego kandydatura - obok Jana Muszkowskiego, Kazimierza Piekarskiego (który w tym czasie przeniósł się do stolicy) i Stefana Rygla - została zgłoszona na stanowisko redaktora naczelnego. Marian Łodyński uważał jednak, iż Grycz nie zgodzi się na przejście do „Przeglądu” z powodu nadmiaru obowiązków. W liście do Adama Łysakowskiego pisał:

\begin{abstract}
Zaraz po posiedzeniu [...] wypowiedziałem się przeciw konieczności dokonywania tych przenosin, gdy wypłynęło pytanie, któż by objął w Warszawie redakcję, zapytałem kolejno i z osobna zarówno dyr. Muszkowskiego, dyr. Rygla i dra Piekarskiego, czy kandydowaliby do tego stanowiska; na to otrzymałem wyraźne oświadczenie, że żaden z nich nie przyjąłby tego redaktorstwa. Pokątnie przebąkują, że może by dr Grycz wziął to na siebie; osobiście nie rozmawiałem w tej sprawie z drem Gryczem, ale nie wątpię, że kto jak kto, ale przecież on najmniej o tym myśli, bo najpierw ma niesłychaną pracę pełniąc obowiązki podwójne, co przy jego obowiązkowości na pewno nerwami porządnie opłaca, a po wtóre przecież jako przedstawiciel władzy, która subwencjonuje organ, a przede wszystkim jako organ resortu nadzorczego w sprawach bibliotekarskich - nie mógłby być redaktorem organu, który musi mieć pełną swobodę wypowiadania się, nawet w takich zagadnieniach, które mogą nosić piętno krytyki w stosunku do Wydziału Bibliotecznego ${ }^{20}$.
\end{abstract}

Ostatecznie wniosek Kossonogi został wstrzymany, do przeniesienia redakcji pisma nie doszło, jego redaktorem zaś pozostał Edward Kuntze.

${ }^{19}$ Por. J. Grycz, O kursy bibliotekarskie, Przegl. Bibliot., 4:1930, z. 2, s. 196.

${ }^{20}$ M. Łodyński do A. Łysakowskiego, Warszawa 1 IV 1931, [w:] Bibliotekarstwo polskie..., s. 47. 
Z dniem 1 stycznia 1930 r. Grycz, jak czytamy w cytowanym liście, został reprezentantem Ministerstwa. Otrzymał stanowisko referenta bibliotek naukowych, a z chwilą otwarcia w tymże roku Biblioteki Narodowej - razem ze Stefanem Dembym zarządzał tą instytucją do 1934 roku $^{21}$. Doświadczenia z tego okresu umożliwiły mu podsumowanie stanu zebranego dotychczas księgozbioru, przytoczenie ważniejszych głosów w tej sprawie specjalistów-bibliotekarzy, m.in. L. Bernackiego, E. Kuntzego, A. Birkenmajera, M. Łodyńskiego i A. Łysakowskiego, a także określenie zadań Biblioteki, zasad gromadzenia zbiorów i kwestii egzemplarza obowiązkowego ${ }^{22}$. Rozważania teoretyczne autor uzupełnił o część praktyczną, w której zrelacjonował realizację powyższych założeń. Wynikało z nich, że mimo starań, charakter Biblioteki Narodowej wciąż był nieskrystalizowany i niejednolity, co wynikało przede wszystkim z warunków jej powstania. Grycz miał tu zapewne na myśli dziesięcioletnie starania dotyczące organizacji książnicy, trudności z uzyskaniem lokalu i finansów na jej działalność23.

W 1933 r. Grycz podjął się na kartach „Przeglądu” wyjaśnienia zmian w bibliotekach szkół wyższych, jakie wprowadziła nowa ustawa z 1933 r. ${ }^{24}$; reorganizacja systemu bibliotek ograniczała się według niego do:

a) tworzenia przez poszczególne biblioteki jednego ośrodka pracy naukowej i jednego warsztatu pracy,

b) poprawnego zarządzania księgozbiorami podległych bibliotek przez kierownika biblioteki głównej,

c) umożliwienia dyrektorowi biblioteki głównej przedstawiania wniosków podczas posiedzeń Komisji Bibliotecznej i Senatu Uczelni,

d) objęcia kompetencjami przez komisje biblioteczne wszystkich spraw zawodowych,

e) doboru odpowiedniego personelu, zgodnego z zajmowanym stanowiskiem ${ }^{25}$.

${ }^{21}$ B. Horodyski, Józef Grycz, [w:] Z zagadnień teorii i praktyki bibliotekarskiej. Studia poświęcone pamięci Józefa Grycza, Wrocław 1961, s. 32-33.

22 J. Grycz, Biblioteka Narodowa na drugim etapie dziatalności, Przegl. Bibliot., 5:1931, z. 2, s. 109-136.

${ }^{23}$ Zbiory Biblioteki Narodowej do II wojny światowej były rozlokowane m.in. w Wyższej Szkole Handlowej przy ul. Rakowieckiej, w pomieszczeniach na Krakowskim Przedmieściu, we wspomnianej Centralnej Bibliotece Wojskowej. Decentralizacja księgozbioru tak ważnej instytucji nie pozostawała bez wpływu na jej organizację i sprawne zarządzanie zwłaszcza, iż w pewnym momencie księgozbiór był rozmieszczony w 11 miejscach w Warszawie. Por. B. Bieńkowska, K. Chamerska, Zarys dziejów książki, Warszawa 1987, s. 353-354.

${ }^{24}$ J. Grycz, O reorganizację bibliotek szkót wyższych, Przegl. Bibliot., 7:1933, z. 2, s. 154-162.

25 Tamże, s. 159. 
Rok później został zamieszczony w „Przeglądzie” artykuł Grycza przedstawiający udział władz państwowych w funkcjonowaniu bibliotek naukowych ${ }^{26}$. Tekst objął nie tylko opis zadań postawionych przed reprezentowanym przez Grycza referatem, lecz także uzasadnienie opieki państwa nad „wszelkimi przejawami kultury”. Kulturotwórcza rola władz w stosunku do zbiorów bibliotecznych z jednej strony gwarantowała dążność do gromadzenia piśmiennictwa w najszerszym znaczeniu tego słowa, z drugiej - obejmowała prawo państwa do ingerencji w politykę biblioteczną, co Grycz tłumaczył interesem i obowiązkiem państwa. Naturalnym rezultatem zwierzchnictwa nad bibliotekami była opieka merytoryczna i finansowa; ta ostatnia umożliwiała odpowiedni wzrost księgozbiorów, utrzymanie książnic na właściwym poziomie, a także sprawiedliwe wynagradzanie pracowników bibliotek.

Grycz wykorzystywał „Przegląd” do publikowania informacji o rozwiązaniach stosowanych $\mathrm{w}$ zagranicznych bibliotekach. W zeszycie 3 z 1938 r. przybliżył problemy związane z wykonywaniem fotokopii dokumentów i mikrofilmów. Artykuł obejmował opis wymagań technicznych urządzeń stosowanych zagranicą oraz uwzględniał problematykę prawną wykonywania odbitek i ich zgodność z literą prawa ${ }^{27}$.

Istotne dla rozwoju bibliotekarstwa w Polsce było zaangażowanie redakcji „Przeglądu” w prace bibliotekarskie na szczeblu międzynarodowym. Oprócz działalności w Komisji Normalizacyjnej w zakresie Bibliotekarstwa, Książki i Czasopiśmiennictwa zorganizowanej przy IFLA, polscy bibliotekarze uczestniczyli m.in. w Światowym Kongresie Dokumentacji Powszechnej, którego głównym przesłaniem było zorganizowanie instytucji ułatwiających pracę naukową. W spotkaniu stronę polską reprezentował Grycz; zaproponował on powołanie takiego centrum, które służyłoby całemu bibliotekarstwu w dzieleniu się osiągnięciami, doświadczeniami i ułatwieniami w zawodzie i dążyło do jego normalizacji i racjonalizacji.

Przedstawiony przez autora projekt, opracowany jako oficjalne stanowisko Związku Bibliotekarzy Polskich, postulował stworzenie i utrzymanie Międzynarodowego Centrum Dokumentacji Bibliotekarskiej przy Międzynarodowej Federacji Stowarzyszeń Bibliotekarskich. Jego zadania zostały sformułowane następująco:

${ }^{26}$ J. Grycz, Rola państwa w stosunku do bibliotek naukowych, Przegl. Bibliot., 8:1934, z. 2, s. 82-97.

${ }^{27}$ Por. J. Grycz, Zagadnienie fotografii w bibliotekarstwie, Przegl. Bibliot., 12:1938, z. 3, s. $145-170$. 
1. udzielanie informacji bibliograficznych i biograficznych,

2. gromadzenie i udostępnianie bibliotekom i członkom IFLA planów budowlanych, ilustracji, kosztorysów, formularzy, tekstów ustaw itd.,

3. działalność instruktażowa i opiniodawcza w zakresie m.in. konserwacji zbiorów, specyfikacji technicznych urządzeń, norm materiałowych itp. ${ }^{28}$

W ślad za organizacją Centrum miało pójść utworzenie jednostek narodowych, podległych głównej instytucji. W Polsce zadania te podjać miała - według Grycza - Biblioteka Narodowa ${ }^{29}$. Mimo, że koncepcja Grycza nie ujrzała światła dziennego i nie przeszła do fazy realizacji, należy traktować ją jako świadectwo zaangażowania środowiska polskiego w prace na szczeblu międzynarodowym oraz jako przyczynek do podobnych działań na poziomie informacji naukowej ${ }^{30}$.

Ważny z punktu widzenia powołania „Przeglądu” jest okolicznościowy tekst Józefa Grycza z okazji dziesięciolecia ukazywania się „Przeglądu Bibliotecznego". Autor szczegółowo przedstawił pierwsze lata funkcjonowania periodyku, okoliczności powstania pisma, warunki tworzenia i statystykę poszczególnych zeszytów, a także kilka szczegółów, dziś trudnych do zweryfikowania w innych źródłach.

Przy omawianiu początków pisma odwołał się do periodyku z lat 1908-09 (od którego zaczerpnął nazwę) i „Bibliotekarza” wydawanego przez Koło Warszawskie Związku. Powołanie do życia „Przeglądu” sprawiło, że stał się on dobrem społecznym wszystkich bibliotekarzy, powinni oni znaleźć w nim interesujące informacje, podane w sposób przystępny, lecz na właściwym poziomie.

28 Por. J. Grycz, O Centrum Dokumentacji Bibliotekarstwa, Przegl. Bibliot., 12:1938, z. 1 , s. 2.

${ }^{29}$ Tamże, s. 4.

${ }^{30}$ Działalność informacyjną i dokumentacyjną w bibliotekarstwie zainicjował założony w 1925 roku Komitet Ekspertów Bibliotecznych, działający przy Międzynarodowym Instytucie Współpracy Intelektualnej Ligi Narodów. W 1927 roku powołano Komitet Bibliotek i Bibliografii, który dwa lata później przekształcił się w IFLA.

Faktyczny wzrost zainteresowania działalnością dokumentacyjną pojawił się w Polsce po II wojnie światowej. W 1949 roku powstał Główny Instytut Dokumentacji NaukowoTechnicznej, w 1960 przekształcony w Centralny Instytut Dokumentacji Naukowo-Technicznej. W tym roku do krajowej sieci informacyjnej włączono dwa tysiące bibliotek fachowych. Kres systemowi położyły zmiany polityczno-gospodarcze 1989 roku, kiedy większość ośrodków zlikwidowano. Kontynuatorem idei do 2002 roku był Instytut Informacji Naukowej, Technicznej i Ekonomicznej. Prawnym następcą placówki jest Instytut Mechanizacji Budownictwa i Górnictwa Skalnego. Por. Informacja naukowa. Rozwój, metody, organizacja, pod red. Zbigniewa Żmigrodzkiego oraz Wiesława Babika i Diany PietruchReizes, Warszawa 2006, s. 68-69, 88; Witryna d. Instytutu INTE - http://www.iinte.edu.pl/ [dostęp 1 września 2010]. 
Grycz prezentując nazwiska autorów artykułów, które ukazały się w ciągu omawianego dziesięciolecia, zauważył, że jest ich niewiele i że część powtarza się, co wyjaśniał niską aktywnością członków Związku. Aby zaktywizować autorów, zaproponował trzy rozwiązania: zamawianie artykułów, prowadzenie teki publikacji i wspólpraca z korespondentami terenowymi, ten ostatni pomysł uznał za najwłaściwszy. Korespondenci byliby odpowiedzialni za pozyskiwanie i „ośmielanie” potencjalnych współpracowników „Przeglądu”.

Opracowanie Grycza zawierało też ocenę objętości, częstotliwości ukazywania się i zawartości periodyku. Zauważył, że objętość rocznika zmieniała się w zależności od liczby zeszytów, i że numery łączone, podwójne i potrójne, nie odpowiadały objętości pojedynczych zeszytów. Wątpliwości budziła również poprawność korekty i druku. Za jeden z ważniejszych czynników, który rozstrzygał o przyszłości periodyku, uważał zapewnienie mu ,stałych i regularnie wpływających środków finansowych", od czego zależało punktualne ukazywanie się zeszytów i ich zawartość.

Grycz traktował „Przegląd Biblioteczny” jako odbicie „życia, potrzeb, dążeń i prac polskich bibliotek i bibliotekarzy”. Prace w nim publikowane miały stawiać nowe problemy i wyjaśniać je - określił je mianem artykułów programowych, ale uważał, że są to często teksty przypadkowe, poruszające rozmaite zagadnienia, lecz niedążące do rozwiązania spornych kwestii. Ułatwieniem mogłoby być podjęcie planowej akcji, której efektem byłoby wskazanie najważniejszych problemów polskiego bibliotekarstwa i ich pomyślnego rozwiązania. Oprócz wymienionej grupy artykułów Grycz wyróżnił jeszcze artykuły „pouczające” i opisowe. Pierwsze pogłębiały wiedzę teoretyczną i umiejętności praktyczne czytelników. Autor widział w nich treści wyjaśniające pewne problemy, usprawniające pracę, często o zakresie ogólniejszym, np. z filozofii, socjologii, czytelnictwa, czy metodyki działalności naukowej. Artykuły opisowe (inaczej sprawozdawcze) zawierały „syntetyczne ujęcie działalności jakiejś biblioteki, czy grupy bibliotek", zapoznawały czytelnika $\mathrm{z}$ organizacją danej placówki, stosowanymi w niej rozwiązaniami technicznymi.

W jubileuszowym artykule znalazła się następująca ocena periodyku:

I z całym naciskiem należy podkreślić, że Przeglą jest organem naukowym i że to obowiązuje! Obowiązuje, mimo iż przeznaczony jest dla wszystkich bibliotekarzy, którzy też powinni w nim znaleźć wiadomości interesujące ich, podane w sposób przystępny, ale na właściwym poziomie. A że zainteresowania bibliote- 
karzy są z natury rzeczy różnorodne, zatem i treść ich fachowego centralnego czasopisma musi być różnorodna ${ }^{31}$.

Za ważną część „Przeglądu” uważał Grycz przedstawianie spraw zawodowych bibliotekarzy - ich potrzeb, warunków i oczekiwań. Pismo miało stać na straży ich interesów. Podsumowując, jeszcze raz podkreślił konieczność regularnego wydawania kolejnych numerów:

Przegląd musi być żywy, aktualny, a więc punktualny. Jest to cecha, która ma równocześnie duże znaczenie propagandowe. A że zależy ona nie tylko od redakcji, lecz w równej mierze od współpracowników, więc do obu stron wypadnie zwrócić prośbę o wzajemną pomoc i w tym kierunku ${ }^{32}$.

Działalność redakcji przerwał wybuch II wojny światowej. W ciągu 13 lat funkcjonowania „Przeglądu” swoje prace opublikowało na jego łamach 158 osób, znanych z imienia i nazwiska lub ukrytych pod kryptonimami. Część z nich podjęła się regularnej współpracy, stale pisując do kolejnych numerów, inni nadesłali teksty jednorazowo.

Józefa Grycza należy zaliczyć do najaktywniejszych autorów, ponieważ opublikował w „Przeglądzie” dziesięć artykułów. Aleksander Birkenmajer napisał sześć artykułów, Marian Łodyński zaś pięć prac. Po cztery prace zamieścili: Eustachy Gaberle, Kazimierz Dobrowolski, Jan Augustyniak, Stefan Vrtel-Wierczyński oraz Adam Łysakowski. Autorami trzech artykułów byli: Zofia Ameisenowa, Helena Hleb-Koszańska, Edward Kuntze, Jan Muszkowski oraz Wacław Olszewicz. Dwa artykuły zamieścili w „Przeglądzie”: Jadwiga Bornsteinowa, Karol Buczek, Mikołaj Dzikowski, Jan Kossonoga, Helena Lipska, Kazimierz Piekarski, Helena Radlińska i Władysław Tadeusz Wisłocki.

Grycz równie chętnie publikował prace mniejsze. Łącznie było ich do wybuchu drugiej wojny światowej 17 . Autor wyprzedził więc Wandę Dobrowolską (15 prac), Włodzimierza Budkę i Mariana Łodyńskiego (po 14 publikacji), Helenę Lipską i Bożennę Szulc-Golską (po 12 prac) i Kazimierza Tyszkowskiego (10 tekstów).

Liczba opublikowanych tekstów, podejmowana tematyka, sposób rozumienia zagadnień polegający nie tylko na ujęciu teoretycznym i historycznym, lecz także praktycznym i prognostycznym świadczą o dużym zaangażowaniu Józefa Grycza w sprawy bibliotekarstwa polskiego, cze-

31 J. Grycz, Pierwsze dziesięciolecie Przeglądu Bibliotecznego, Przegl. Bibliot., 11:1937, z. 1, s. 1-2.

32 Tamże, s. 6, 13-14. 
go wynikiem była konsekwentna polityka biblioteczna i systematyczne wsparcie prac Związku Bibliotekarzy Polskich. Należy go traktować nie tylko jako współtwórcę „Przegląd Bibliotecznego” i jego sekretarza, ale także jako aktywnego autora ważnych artykułów i drobnych przyczynków do dziejów bibliotekarstwa polskiego w dwudziestoleciu międzywojennym.

\section{Summary}

\section{Józef Grycz's Contribution to the Periodical Przeglad Biblioteczny (1927-1939)}

Przeglad Biblioteczny is the oldest Polish scientific periodical devoted to library science. The article recounts the activities of Józef Grycz with relation to the establishing of the journal in 1927, and next his professional engagement in the editorial works (through 1928). The author discusses Grycz's undertakings chiefly on the basis of his articles published in Przeglad Biblioteczny, and the fragments of his correspondence with Adam Lysakowski published by Maria Dembowska. The matters which concerned Grycz the most were related to the organization and functioning of libraries in Poland. 